\title{
Slope Maps of the San Francisco Bay Region, California: A Digital Database
}

\author{
By SCOTT E. GRAHAM ${ }^{1}$ and RICHARD J. PIKE ${ }^{1}$
}

A detailed slope map has been derived from the

most accurate data on the region's topography,

35,000,000 digital elevations spaced 30 meters apart

\section{OPEN-FILE REPORT 98-766}

\section{8}

This report is preliminary and has not been reviewed for conformity with U.S. Geological Survey editorial standards or with the North American Stratigraphic Code. Any use of trade, product, or firm names is for descriptive purposes only and does not imply endorsement by the U.S. Government.

This database, identified as "Slope Maps of the San Francisco Bay Region, California: A Digital Database," has been approved for release and publication by the Director of the USGS. Although this database has been subjected to rigorous review and is substantially complete, the USGS reserves the right to revise the data pursuant to further analysis and review. Furthermore, it is released on condition that neither the USGS nor the United States Government may be held liable for any damages resulting from its authorized or unauthorized use.

${ }^{1} 345$ MIDDLEFIELD RD., MS 975, MENLO PARK, CA 94025

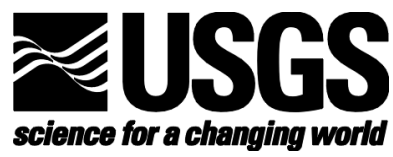




\section{PREFACE}

Topography, the configuration of the land surface, plays a major role in various natural processes that have helped shape the ten-county San Francisco Bay region and continue to affect its development. Such processes include a dangerous type of landslide, the debris flow (Ellen and others, 1997) as well as other modes of slope failure that damage property but rarely threaten life directly-slumping, translational sliding, and earthflow (Wentworth and others, 1997). Different types of topographic information at both local and regional scales are helpful in assessing the likelihood of slope failure and the mapping the extent of its past activity, as well as addressing other issues in hazard mitigation and land-use policy. The most useful information is quantitative. This report provides detailed digital data and plottable map files that depict in detail the most important single measure of ground-surface form for the Bay region, slope angle. We computed slope data for the entire region and each of its constituent counties from a new set of 35,000,000 digital elevations assembled from 200 local contour maps.

\section{INTRODUCTION TO THE DIGITAL DATABASE}

This Open-File report is a digital map database. This pamphlet serves to introduce and describe the digital data. There are no paper maps included in the Open-File report. The digital data does include, however, PostScript and PDF plot files containing images of the map sheets depicting slope angle of the San Francisco Bay region and each of its ten constituent counties.

For those interested in the slope maps, but who do not use an ARC/INFO compatible Geographic Information System (GIS), and who would like to obtain the paper maps, 11 PostScript plot files and $11 \mathrm{PDF}$ files containing map images of the data in the digital database have been included in the database package (please see the section "PostScript and PDF Plot Files Packages," page 9). A PostScript plot file and PDF file showing problematic areas in the DEM from which the slope database was derived are also included. Note that the PostScript plot files require gzip and tar utilities to access the files (see below for explanation).

For those without computer capability, we can provide users with the PostScript plot files or PDF files on tape that can be used by other vendors. Additionally, plots can be ordered from the USGS via the plot-on-demand program once it has been initiated (please see the section " Obtaining Plots from USGS Open-File Services" page 12)

The content and character of the database, methods of obtaining it, and processes of extracting the map database from the tar file are described herein. The map database itself, consisting of eleven ARC/INFO GRIDS and two ARC/INFO coverages, can be obtained over the Internet or by magnetic tape copy, as described below.

The database was compiled using ARC/INFO 7.1.1, a commercial Geographic Information System (Environmental Systems Research Institute, Redlands, California), with version 3.0 of the menu interface ALACARTE (Fitzgibbon and Wentworth, 1991, Fitzgibbon, 1991, Wentworth and Fitzgibbon, 1991). The ARC/INFO GRIDS are stored in compressed tar files, and the coverages 
are stored in uncompressed ARC export format (ARC/INFO version 7.x) in a compressed UNIX tar (tape archive) file. All data files have been compressed, and may be uncompressed with gzip, which is available free of charge over the Internet via links from the USGS Public Domain Software page (http://edcwww.cr.usgs.gov/doc/edchome/ndcdb/public.html). A tar utility is required to extract the databases from tar files. This utility is included in most UNIX systems, and can be obtained free of charge via the Internet from Internet Literacy's Common Internet File Formats Webpage (http://www.matisse.net/files/formats.html) for Macintosh and Windows. ARC/INFO export files (files with the .e00 extension) can be converted into ARC/INFO coverages in ARC/INFO (see below) and can be read by some other Geographic Information Systems, such as MapInfo via ArcLink and ESRI's ArcView.

\section{THE DIGITAL SLOPE-MAP DATABASE}

The new slope maps supersede earlier mechanized portrayals of the area. A 1:125,000-scale map of the ten-county region (U.S. Geological Survey, 1972), derived photomechanically from a contour map (U.S. Geological Survey, 1970), had previously been the only medium-scale slope map of the Bay region.

The data from which the new maps were computed consist of a digital elevation model (DEM), an $(\mathrm{X}, \mathrm{Y})$ array of terrain heights spaced $30 \mathrm{~m}$ apart. We assembled the data set from 204 separate DEM's derived from topographic maps in the USGS 7.5' series (see the quadrangle index map, Figure 1 in Pike, 1997). Because all constituent DEM's were created by the recent and higheraccuracy "Level II" procedures that interpret elevations from digital line graphs of the map contours (U.S. Geological Survey, 1993), these maps are free from the striped artifacts that mar shaded-relief portrayals computed from older 7.5' DEM's. A few problems in the DEM remain, principally minor edgematch errors, and are identified in a separate map.

At 1:275,000 scale, the full Bay Region map comprises some 35,000,000 rectangular picture elements (pixels), each about $0.11 \mathrm{~mm}$ across. The array measures 7743 cells in the east-west direction and 7423 cells in the north-south direction. Pixels of the ten 1:125,000-scale county maps, at about $0.24 \mathrm{~mm}$ across, are below the size at which the human eye begins to resolve individual elements.

Drainage lines and nearshore bathymetry, topographic contours, and major roads from an existing digital base (Aitken, 1997) were added to terrain slope-angle on all 11 maps. To facilitate rapid location of specific areas of interest the ten 1:125,000-scale county maps carry a detailed road network and major place names (Aitken, 1997). A two-km buffer zone around all counties was added to each 1:125,000-scale map to provide context for any terrain details at or near the county boundary (mapped by a white-bounded black line in the plotfiles).

The database for the slope map consists of ARC/INFO GRIDs for the region as a whole and for each of the ten counties, an ARC/INFO vector coverage identifying areas of the DEM compilation that have edgematch or other problems, PostScript map-image files for each of those 11 areas, a PostScript version of a map showing the problematic areas, and a PostScript version of this text. Additionally, a PDF file derived from each of the PostScript plot files has been included. 
The 2047.5 minute DEM's were compiled into a single dataset using the LATTICEMERGE command in ARC/INFO. Most of the inconsistencies and edgematch problems between adjacent quadrangles were cleaned up using the FOCALMEAN function in ARC/INFO GRID. A number of these problems still exist (see of98-766_31.ps or of98-766_31.pdf). The slope grid (sfbr-sl) was prepared using the SLOPE function in ARC/INFO GRID, with slope being represented by percent rise. The slope is calculated by identifying the maximum rate of change between each cell and its neighbors in a $3 \times 3$ cell window. Slope angle at 30 -meter resolution varies from $0 \%$ to $100 \%$.

We selected 6 intervals of terrain slope angle, designated in the plotfiles by different colors, to enhance presentation of the new data. Slope intervals and their associated colors are:

$$
\begin{gathered}
0-5 \% \text { purple } \\
>5-15 \% \text { blue } \\
>15-30 \% \text { green } \\
>30-50 \% \text { yellow } \\
>50-70 \% \text { orange } \\
>70 \% \text { red }
\end{gathered}
$$

The map database itself is rather simple, consisting of attributed GRID cells stored in Universal Transverse Mercator (UTM) projection (Table 1).

Table 1 - Map Projection

$\begin{array}{ll}\text { PROJECTION } & \text { UTM } \\ \text { UNITS } & \text { meters } \\ \text { ZONE } & 10 \\ \text { DATUM } & \text { NAD27 } \\ \text { PARAMETERS } & \text { none }\end{array}$

Content of the map database can be described in terms of the grid cells comprising the map. Descriptions of the database fields use the terms explained in Table 2.

Table 2 - Field Definition Terms

ITEM NAME

WIDTH

OUTPUT

TYPE

N.DEC name of the database field (item)

maximum number of digits or characters stored output width B-binary integer, F-binary floating-point number, I-ASCII integer, C-ASCII character string number of decimal places maintained for floatingpoint numbers 
The database format of the grid is described in Tables 3 and 4, which show the format of the GRID attribute and statistics tables.

Table 3 - Contents of GRID Value Attribute Table (<GRIDNAME>.VAT)

$\begin{array}{lcccc}\text { ITEM NAME } & \text { WIDTH } & \text { OUTPUT } & \text { TYPE } & \text { N.DEC } \\ \text { AREA } & 4 & 10 & \text { B } & -- \\ \text { COUNT } & 4 & 10 & \text { B } & --\end{array}$

Table 4 - Contents of GRID Statistics Table (<GRIDNAME>.STA)

$\begin{array}{ccccc}\text { ITEM NAME } & \text { WIDTH } & \text { OUTPUT } & \text { TYPE } & \text { N.DEC } \\ \text { MIN } & 8 & 15 & \text { F } & 3 \\ \text { MAX } & 8 & 15 & \text { F } & 3 \\ \text { MEAN } & 8 & 15 & \text { F } & 3 \\ \text { STDV } & 8 & 15 & \text { F } & 3\end{array}$

\section{LINES}

The lines (arcs) are recorded as strings of vectors and are described in the arc attribute table (tables 5 and 7). They define the boundaries of the map units, the boundaries of open bodies of water, and the map boundaries. These distinctions, including the geologic identities of the unit boundaries, are recorded in the LTYPE field according to the line types listed in tables 6 and 8.

Table 5 - Contents of the Arc Attribute Table (DEMPROBS.AAT)

ITEM NAME WIDTH OUTPUT TYPE N. DEC

\begin{tabular}{|c|c|c|c|c|c|}
\hline FNODE\# & 4 & 5 & B & & starting node of arc (from node) \\
\hline TNODE\# & 4 & 5 & B & & ending node of arc (to node) \\
\hline LPOLY\# & 4 & 5 & B & & polygon to the left of the arc \\
\hline RPOLY\# & 4 & 5 & B & & polygon to the right of the arc \\
\hline LENGTH & 4 & 12 & $\mathrm{~F}$ & 3 & length of arc in meters \\
\hline$<$ coverage>\# & 4 & 5 & B & & unique internal control number \\
\hline$<$ coverage >-ID & 4 & 5 & B & & unique identification number \\
\hline LTYPE & 35 & 35 & $\mathrm{C}$ & & line type (see Tables 4 and 5) \\
\hline SEL & 1 & 1 & I & & $\begin{array}{l}\text { user defined field used to save a } \\
\text { selected set }\end{array}$ \\
\hline SYMB & 3 & 3 & $\mathrm{I}$ & & $\begin{array}{l}\text { user defined field used to save } \\
\text { symbol assignments (such as color) }\end{array}$ \\
\hline
\end{tabular}


Table 6 - Line Types Recorded in the LTYPE Field (DEMPROBS.AAT)

problem

Table 7 - Contents of the Arc Attribute Table (SFBR-QI.AAT)

ITEM NAME WIDTH OUTPUT TYPE N. DEC

\begin{tabular}{|c|c|c|c|c|c|}
\hline FNODE\# & 4 & 5 & B & & starting node of arc (from node) \\
\hline TNODE\# & 4 & 5 & B & & ending node of arc (to node) \\
\hline LPOLY\# & 4 & 5 & B & & polygon to the left of the arc \\
\hline RPOLY\# & 4 & 5 & B & & polygon to the right of the arc \\
\hline LENGTH & 4 & 12 & $\mathrm{~F}$ & 3 & length of arc in meters \\
\hline <coverage>\# & 4 & 5 & B & & unique internal control number \\
\hline <coverage>-ID & 4 & 5 & B & & unique identification number \\
\hline LTYPE & 35 & 35 & $\mathrm{C}$ & & line type (see Table 7) \\
\hline SEL & 1 & 1 & I & & $\begin{array}{l}\text { user defined field used to save a } \\
\text { selected set }\end{array}$ \\
\hline SYMB & 3 & 3 & I & & $\begin{array}{l}\text { user defined field used to save } \\
\text { symbol assignments (such as color) }\end{array}$ \\
\hline TICS & 4 & 4 & $\mathrm{C}$ & & \\
\hline
\end{tabular}

Table 8 - Line Types Recorded in the LTYPE Field (SFBR-QI.AAT)

15

7.5

santa cruz

\section{AREAS}

Map units (polygons) are described in the polygon attribute table (tables 8 and 10). The identities of the map units are shown in tables 9 and 11 . 
Table 9 - Content of the Polygon Attribute Tables (DEMPROBS.PAT)

ITEM NAME WIDTH OUTPUT TYPE N. DEC

\begin{tabular}{|c|c|c|c|c|c|}
\hline AREA & 4 & 12 & $\mathrm{~F}$ & 3 & area of polygon in square meters \\
\hline PERIMETER & 4 & 12 & $\mathrm{~F}$ & 3 & length of perimeter in meters \\
\hline <coverage>\# & 4 & 5 & B & & unique internal control number \\
\hline <coverage>-ID & 4 & 5 & B & & unique identification number \\
\hline PTYPE & 35 & 35 & $\mathrm{C}$ & & unit label (see Table 10) \\
\hline SEL & 1 & 1 & I & & $\begin{array}{l}\text { user defined field used to save } \\
\text { a selected set }\end{array}$ \\
\hline SYMB & 3 & 3 & I & & $\begin{array}{l}\text { user defined field used to save } \\
\text { symbol assignments (such as color) }\end{array}$ \\
\hline
\end{tabular}

Table 10 - Polygon types recorded in the PTYPE field (DEMPROBS.PAT)

problem

Table 11 - Content of the Polygon Attribute Tables (SFBR-QI.PAT)

ITEM NAME WIDTH OUTPUT TYPE N. DEC

$\begin{array}{llllll}\text { AREA } & 4 & 12 & \mathrm{~F} & 3 & \text { area of polygon in square meters } \\ \text { PERIMETER } & 4 & 12 & \mathrm{~F} & 3 & \text { length of perimeter in meters } \\ \text { <coverage>\# } & 4 & 5 & \mathrm{~B} & & \text { unique internal control number } \\ \text { <coverage>-ID } & 4 & 5 & \mathrm{~B} & & \text { unique identification number } \\ \text { NAME } & 35 & 35 & \mathrm{C} & & 7.5 \text { minute quadrangle name }\end{array}$

Table 12 - Polygon types recorded in the NAME field (SFBR-QI.PAT)

$\begin{array}{lll}\text { AETNA SPRINGS } & \text { BODEGA HEAD } & \text { CHILES VALLEY } \\ \text { ALLENDALE } & \text { BOLINAS } & \text { CHITTENDEN } \\ \text { ALTAMONT } & \text { BOULDIN ISLAND } & \text { CLARKSBURG } \\ \text { ANNAPOLIS } & \text { BRENTWOOD } & \text { CLAYTON } \\ \text { ANO NUEVO } & \text { BRIONES VALLEY } & \text { CLIFTON COURT } \\ \text { ANTIOCH NORTH } & \text { BROOKS } & \text { FOREBAY } \\ \text { ANTIOCH SOUTH } & \text { BYRON HOT SPRINGS } & \text { CLOVERDALE } \\ \text { ARCHED ROCK } & \text { CALAVERAS RESERVOIR COPPER MOUNTAIN } \\ \text { ASTI } & \text { CALISTOGA } & \text { CORDELIA } \\ \text { BENICIA } & \text { CAMP MEEKER } & \text { COTATI } \\ \text { BIG BASIN } & \text { CAPELL VALLEY } & \text { COURTLAND } \\ \text { BIG FOOT MTN } & \text { CASTLE ROCK RIDGE } & \text { CREVISON PEAK } \\ \text { BIRD VALLEY } & \text { CAZADERO } & \text { CUPERTINO } \\ \text { BIRDS LANDING } & \text { CEDAR MTN } & \text { CUTTINGS WHARF }\end{array}$




\begin{tabular}{|c|c|c|}
\hline DAVENPORT & LATHROP & PETALUMA RIVER \\
\hline DAVIS & LAUREL & PIGEON POINT \\
\hline DENVERTON & LIBERTY ISLAND & PLANTATION \\
\hline DETERT RESERVOIR & LICK OBSERVATORY & POINT BONITA \\
\hline DIABLO & LIVERMORE & POINT REYES NE \\
\hline DIXON & LOMA PRIETA & REDWOOD POINT \\
\hline DOUBLE POINT & LONE TREE CREEK & RICHMOND \\
\hline DOZIER & LOS GATOS & RIO VISTA \\
\hline DRAKES BAY & MADISON & RIPON \\
\hline DUBLIN & MANTECA & RUTHERFORD \\
\hline DUNCAN MILLS & MARE ISLAND & SACRAMENTO WEST \\
\hline ELDORADO BEND & MARIPOSA PEAK & SAN FELIPE \\
\hline ELMIRA & MARK WEST SPRINGS & SAN FRANCISCO \\
\hline ESPARTO & MCGUIRE RIDGE & NORTH \\
\hline EYLAR MTN & MENDENHALL SPRINGS & SAN FRANCISCO \\
\hline FAIRFIELD NORTH & MERRITT & SOUTH \\
\hline FAIRFIELD SOUTH & MIDDLETOWN & SAN GERONIMO \\
\hline FELTON & MIDWAY & SAN GREGORIO \\
\hline FORT ROSS & MILPITAS & SAN JOSE EAST \\
\hline FRANKLIN POINT & MINDEGO HILL & SAN JOSE WEST \\
\hline GEYSERVILLE & MISSISSIPPI CREEK & SAN LEANDRO \\
\hline GILROY & MONTARA MTN & SAN MATEO \\
\hline GILROY HOT SPRINGS & MONTICELLO DAM & SAN QUENTIN \\
\hline GLEN ELLEN & MORGAN HILL & SAN RAFAEL \\
\hline GRAYS BEND & MOUNT ST HELENA & SANTA CRUZ \\
\hline GUALALA & MOUNTAIN VIEW & SANTA ROSA \\
\hline GUDE MOUNTAIN & MT BOARDMAN & SANTA TERESA HILLS \\
\hline GUERNEVILLE & MT DAY & SAUNDERS REEF \\
\hline GUINDA & MT GEORGE & SAXON \\
\hline HALF MOON BAY & MT MADONNA & SEARS POINT \\
\hline HAYWARD & MT SIZER & SEBASTOPOL \\
\hline HEALDSBURG & MT STAKES & SOLYO \\
\hline HONKER BAY & MT VACA & SONOMA \\
\hline HUNTERS POINT & MUSTANG PEAK & SOQUEL \\
\hline INVERNESS & NAPA & ST HELENA \\
\hline ISABEL VALLEY & NEWARK & STEWARTS POINT \\
\hline ISLETON & NILES & TASSAJARA \\
\hline JERICHO VALLEY & NOVATO & TAYLOR MONUMENT \\
\hline JERSEY ISLAND & OAKLAND EAST & THE GEYSERS \\
\hline JIMTOWN & OAKLAND WEST & THREE SISTERS \\
\hline KENWOOD & ORESTIMBA PK & TOMALES \\
\hline KNIGHTS LANDING & PACHECO PASS & TOMBS CREEK \\
\hline KNOXVILLE & PACHECO PEAK & TRACY \\
\hline LA COSTA VALLEY & PALO ALTO & TWO ROCK \\
\hline LA HONDA & PATTERSON & UNION ISLAND \\
\hline LAKE BERRYESSA & PETALUMA & VALLEY FORD \\
\hline LAS TRAMPAS RIDGE & PETALUMA POINT & VERNALIS \\
\hline
\end{tabular}


VERONA

VINE HILL

WALNUT CREEK

WALTER SPRINGS

WARM SPRINGS DAM

WATSONVILLE EAST

\author{
WATSONVILLE WEST \\ WESTLEY \\ WHISPERING PINES \\ WILCOX RIDGE \\ WINTERS \\ WOODLAND
}

WOODSIDE

WOODWARD ISLAND

YOUNTVILLE

ZAMORA

\section{DATABASE CONTENTS}

The digital map database consists of digital files representing the five parts of the database, some of which are presented in more than one format. The names of the files are unique designators based on the report identifier, of $98-766$, followed by part numbers and an extension indicating file type. The larger files, which have been compressed with gzip, have .gz extensions as well.

1. Revision List

A list of the parts of the report and at what version number of the report each was last revised (if at all) followed by a chronologic list that describes any revisions.
a. of98-766revs_1a.txt
ASCII file

2. Open File Text

The text of the open-file report (this document), which describes the database and how to obtain it.
a. of98-766_2a.txt
unformatted ASCII text
b. of98-766_2b.ps
PostScript file
c. of98-766_2c.pdf
PDF file 
3. Slope Database

A separate GRID (ARC/INFO raster digital map database) is included for each of the ten counties in the San Francisco Bay region, as well as one for the Bay region as a whole. The GRIDs, which have been packaged in tar (tape archive) files, are described below.

\begin{tabular}{|c|c|c|c|}
\hline $\begin{array}{l}\text { ARC/INFO } \\
\text { export file } \\
\text { or tar file }\end{array}$ & $\begin{array}{l}\text { Size of gzip } \\
\text { compressed } \\
\text { tar file } \\
\text { (uncompressed) }\end{array}$ & $\begin{array}{l}\text { Resultant } \\
\text { Grid, } \\
\text { Coverage } \\
\text { or file(s) }\end{array}$ & $\begin{array}{l}\text { Description of } \\
\text { Grid or Coverage }\end{array}$ \\
\hline of98-766_3a.tar & $17.5 \mathrm{MB}(27.4 \mathrm{MB})$ & sfbr-sl & SF Bay region slope GRID \\
\hline of98-766_3b.tar & $1.6 \mathrm{MB}(2.5 \mathrm{MB})$ & al-sl & Alameda County slope GRID \\
\hline of98-766_3c.tar & $1.5 \mathrm{MB}(2.4 \mathrm{MB})$ & cc-sl & Contra Costa County slope GRID \\
\hline of98-766_3d.tar & $1.2 \mathrm{MB}(2.0 \mathrm{MB})$ & ma-sl & Marin County slope GRID \\
\hline of98-766_3e.tar & $1.9 \mathrm{MB}(2.9 \mathrm{MB})$ & na-sl & Napa County slope GRID \\
\hline of98-766_3f.tar & $144 \mathrm{~KB}(320 \mathrm{~KB})$ & sf-sl & San Francisco County slope GRID \\
\hline of98-766_3g.tar & 1.1 MB (1.7 MB) & sm-sl & San Mateo County slope GRID \\
\hline of98-766_3h.tar & 3.2 MB (4.6 MB) & scl-sl & Santa Clara County slope GRID \\
\hline of98-766_3i.tar & $1.3 \mathrm{MB}(1.9 \mathrm{MB})$ & scr-sl & Santa Cruz County slope GRID \\
\hline of98-766_3j.tar & $1.2 \mathrm{MB}(2.2 \mathrm{MB})$ & sol-sl & Solano County slope GRID \\
\hline of98-766_3k.tar & $3.5 \mathrm{MB}(5.3 \mathrm{MB})$ & son-sl & Sonoma County slope GRID \\
\hline
\end{tabular}

4. Quadrangle Index and DEM Problems databases

The data files representing the lines and polygons of the quadrangle index and problems associated with the SF Bay region DEM from which the slope map was derived (ARC export and ARCVIEW shape formats).

\begin{tabular}{|c|c|c|c|}
\hline $\begin{array}{l}\text { ARC/INFO } \\
\text { export file } \\
\text { or tar file }\end{array}$ & $\begin{array}{l}\text { Size of gzip } \\
\text { compressed } \\
\text { tar file } \\
\text { (uncompressed) }\end{array}$ & $\begin{array}{l}\text { Resultant } \\
\text { Grid, } \\
\text { Coverage } \\
\text { or file(s) }\end{array}$ & $\begin{array}{l}\text { Description of } \\
\text { Grid or Coverage }\end{array}$ \\
\hline of98-766_4a.e00 & $256 \mathrm{~KB}(1.1 \mathrm{MB})$ & sfbr-qi & $\begin{array}{l}\text { SF Bay region Quadrangle Index } \\
\text { (ARC/INFO export file) }\end{array}$ \\
\hline of98-766_4b.tar & $272 \mathrm{~KB}(912 \mathrm{~KB})$ & $\begin{array}{l}\text { sfbrqiln } \\
\text { sfbrqipy }\end{array}$ & $\begin{array}{l}\text { SF Bay region Quadrangle Index } \\
\text { (ARCVIEW shape files) }\end{array}$ \\
\hline of98-766_4c.e00 & $7 \mathrm{~KB}(27 \mathrm{~KB})$ & demprobs & $\begin{array}{l}\text { DEM problem areas (ARC/INFO } \\
\text { export file) }\end{array}$ \\
\hline of98-766_4d.tar & $4 \mathrm{~KB}(22 \mathrm{~KB})$ & $\begin{array}{l}\text { probsln } \\
\text { probspy }\end{array}$ & $\begin{array}{l}\text { DEM problem areas (ARCVIEW } \\
\text { shape files) }\end{array}$ \\
\hline
\end{tabular}


For the map identifying problematic areas in the source DEM, and the accompanying quadrangle index map, only a coverage for the entire SF Bay region is included. There are no separate county databases. The coverages, along with their associated INFO directory have been converted to uncompressed ARC/INFO export files. ARC export files promote ease of data handling, and are usable by some Geographic Information Systems in addition to ARC/INFO (see below for a discussion of working with export files). The ARCVIEW shapefile packages each consist of three files - <name>.dbf, <name>.shp, and <name>.shx.

5. PostScript and PDF plot files

Slope maps of the SF Bay Region and each of its ten constituent counties in PostScript and PDF formats. Note, the PDF files have not been compressed. The file sizes listed for them below are the actual sizes of the PDF files.

Plot file
-------------
of98-766_5a.ps
of98-766_5b.ps
of98-766_5c.ps
of98-766_5d.ps
of98-766_5e.ps
of98-766_5f.ps
of98-766_5g.ps
of98-766_5h.ps
of98-766_5i.ps
of98-766_5j.ps
of98-766_5k.ps
of98-766_51.ps

of98-766_5a.pdf of98-766_5b.pdf of98-766_5c.pdf of98-766_5d.pdf of98-766_5e.pdf of98-766_5f.pdf of98-766_5g. pdf of98-766_5h.pdf of98-766_5i.pdf of98-766_5j.pdf of98-766_5k.pdf of98-766_51.pdf

\section{Size of gzip compressed plot file (uncompressed)}

$24 \mathrm{MB}(371 \mathrm{MB})$ 7.4 MB (52.2 MB)

6.1 MB (46.8 MB)

4.8 MB (40 MB)

$7.8 \mathrm{MB}(50 \mathrm{MB})$

$1.2 \mathrm{MB}(9.5 \mathrm{MB})$

4.2 MB (33.8 MB) $11.5 \mathrm{MB}$ (73.3 MB)

$5.8 \mathrm{MB}$ (42.1 MB)

6.2 MB (51 MB) 11.5 MB (92.3 MB) $5.8 \mathrm{MB}(21 \mathrm{MB})$

$10.3 \mathrm{MB}$

$5.4 \mathrm{MB}$

$4.6 \mathrm{MB}$

$3.4 \mathrm{MB}$

$5.4 \mathrm{MB}$

$968 \mathrm{~KB}$

3.0 MB

$8.1 \mathrm{MB}$

4.0 MB

4.7 MB

$7.6 \mathrm{MB}$

$5.7 \mathrm{MB}$
Description of plot file

SF Bay region slope map (PostScript)

Alameda County slope map (PostScript)

Contra Costa County slope map (PostScript)

Marin County slope map (PostScript)

Napa County slope map (PostScript)

San Francisco County slope map (PostScript)

San Mateo County slope map (PostScript)

Santa Clara County slope map (PostScript)

Santa Cruz County slope map (PostScript)

Solano County slope map (PostScript)

Sonoma County slope map (PostScript)

Map of problems associated with SF

Bay region DEM (PostScript)

SF Bay region slope map (PDF)

Alameda County slope map (PDF)

Contra Costa County slope map (PDF)

Marin County slope map (PDF)

Napa County slope map (PDF)

San Francisco County slope map (PDF)

San Mateo County slope map (PDF)

Santa Clara County slope map (PDF)

Santa Cruz County slope map (PDF)

Solano County slope map (PDF)

Sonoma County slope map (PDF)

Map of problems associated with SF

Bay region DEM (PDF) 


\section{OBTAINING PLOTS FROM USGS OPEN-FILE SERVICES}

NOTE: As of this writing, plot-on-demand is not available from USGS. This service may not begin until 1999.

U.S. Geological Survey is planning to provide a plot-on-demand service for map files, such as those described in this report, through Open-File Services. In order to obtain plots, contact Open-File Services at:

USGS Information Services

Box 25286

Denver Federal Center

Denver, CO 80225-0046

(303) 202-4200

1-800-USA-MAPS

FAX: (303) 202-4695

e-mail: infoservices@usgs.gov

Be sure to include with your request the Open-File Report number and the exact names, as listed in the Database Contents section above, of the plot file(s) you require. An Open-File Report number and its letter alone are not sufficient, unless you are requesting plots of all the plot files for this report (as many as 12 plot files!).

\section{POSTSCRIPT PLOT FILE PACKAGE}

For those interested in the any of the slope maps of the SF Bay region who don't use an ARC/INFO compatible GIS system, but would like to obtain any of the paper maps, we have included separate PostScript and PDF plot files for each of the ten counties and the Bay Region, as well as for the map delineating problem areas in the composite DEM for the SF Bay region.

The plot files are available in any of the three ways described below, including the World Wide Web pages. The plot files have been compressed with gzip and they must be uncompressed to access them. The compression utility gzip is available free of charge for Windows, Macintosh and Unix platforms via the Internet from the gzip home page (http://w3.teaser.fr/ jlgailly/gzip).

The PostScript images are as large as 36 inches wide by 40 inches high, so they require a large plotter to produce paper copies at the intended scale. Because this release is primarily a digital database, the plot files (and plots derived therefrom) has not been edited to conform to U.S. Geological Survey standards. 


\section{OBTAINING THE POSTSCRIPT OR PDF PLOT FILES}

The PostScript and PDF plot files can be obtained in any of three ways:

1. Sending a tape with request

A compressed plot file(s) can be obtained by sending a tape with request to:

SFBR Slope Map Plot File

c/o Database Coordinator

U.S. Geological Survey

345 Middlefield Road, MS 975

Menlo Park, CA 94025

The compressed tar file will be returned on the tape. The acceptable tape types are:

2.3 or $5.0 \mathrm{~GB}, 8 \mathrm{~mm}$ Exabyte tape.

Be sure to include with your request the Open-File Report number and the exact names, as listed in the Database Contents section above, of the plot file(s) you require. An Open-File Report number and its letter alone are not sufficient, unless you are requesting plots of all the plot files for that report (as many as 12 plot files!).

2. Anonymous ftp over the Internet

To obtain plotfiles by ftp:

The files in these reports are stored on the U.S. Geological Survey Western Region FTP server. The Internet ftp address of this server is:

ftp://wrgis.wr.usgs.gov

The user should log in with the user name 'anonymous' and then input their e-mail address as the password. This will give the user access to all the publications available via ftp from this server.

The files in this report are stored in the subdirectory:

pub/open-file/of98-766

3. From the Western Region Geologic Information Web Page.

The U.S. Geological Survey now supports a set of graphical pages on the World Wide Web. Digital publications (including this one) can be accessed via these pages. The web server for digital publications from the Western Region is "http://wrgis.wr.usgs.gov". Once at the main page, click on 'Geologic Map Databases' under the heading 'Data Online'; next click on 'California.' Scroll down to the section for this database and click on the Open-File button to get to this publication's web page. Click on 'Open-File Report 98-766'; this will take you to the 
web page for this database. Set your web browser to save to a local disk and click on the link for the desired file to download the compressed PostScript plot file or PDF file.

For those interested in the slope map of the bay region, any of its ten constituent counties, or the map showing problems with the SF Bay region DEM who do not use computers, we will also provide any of the PostScript or PDF plot files on digital tape for use by other vendors. The PostScript or PDF plot files can be obtained by sending a tape with request and return address to:

\author{
SFBR Slope Map Plot File \\ c/o Database Coordinator \\ U.S. Geological Survey \\ 345 Middlefield Road, MS 975 \\ Menlo Park, CA 94025
}

The compressed plot file(s) will be returned on the tape. The acceptable tape types are:

\title{
2.3 or $5.0 \mathrm{~GB}, 8 \mathrm{~mm}$ Exabyte tape.
}

Be sure to include with your request the Open-File Report number and the exact names, as listed in the Database Contents section above, of the plot file(s) you require. An Open-File Report number and its letter alone are not sufficient, unless you are requesting plots of all the plot files for this report (as many as 12 plot files!).

Make sure your vendor is capable of reading these tape types and this PostScript plot file. Important information regarding tape file format is included in the section "PostScript Plot Files" below, so be certain to provide a copy of this document to your vendor.

\section{OBTAINING DIGITAL DATABASES}

The digital database package can be obtained in any of three ways:

1. Sending a tape with request

A compressed tar file(s) of the slope map database for the bay region, any of its ten counties, or the DEM problems coverage can be obtained by sending a tape with request and return address to:

\author{
SFBR Slope Map Database \\ c/o Database Coordinator \\ U.S. Geological Survey \\ 345 Middlefield Road, M/S 975 \\ Menlo Park, CA 94025
}

The compressed tar file(s) will be returned on the tape. The acceptable tape types are:

2.3 or $5.0 \mathrm{~GB}, 8 \mathrm{~mm}$ Exabyte tape. 
Be sure to include with your request the Open-File Report number and the exact names, as listed in the Database Contents section above, of the database file(s) you require. An Open-File Report number and its letter alone are not sufficient, unless you are requesting all of the database files for this report (as many as 15).

2. Anonymous ftp over the Internet

To obtain plotfiles by ftp:

The files in these reports are stored on the U.S. Geological Survey Western Region FTP server. The Internet ftp address of this server is:

ftp://wrgis.wr.usgs.gov

The user should log in with the user name 'anonymous' and then input their e-mail address as the password. This will give the user access to all the publications available via ftp from this server.

The files in this report are stored in the subdirectory:

pub/open-file/of98-766

3. From the Western Region Geologic Information Web Page.

To obtain the tar file via the World Wide Web:

The U.S. Geological Survey now supports a set of graphical pages on the World Wide Web. Digital geologic publications (including this one) can be accessed via these pages. The web page for digital geologic publications from the Western Region (including this one) is "http://wrgis.wr.usgs.gov". Once at the main page, click on 'Geologic Map Databases' under the heading 'Data Online'; next click on 'California.' Scroll down to get to the listing for this database. Click on 'Open-File Report 98-766'; this will take you to the web page for this database. Set your web browser to save to a local disk and click on the link for the desired database to download the compressed tar file or ARC/INFO export file.

\section{CONVERTING ARC EXPORT FILES}

ARC export files are converted to ARC coverages using the ARC command IMPORT with the option COVER. Change directories to the database directory. From the ARC command line type:

Arc: import cover <filename>.e00<output coverage> 
ARC export files can also be read by some other Geographic Information Systems. Please consult your GIS documentation to see if you can use ARC export files and the procedure to import them. 


\section{References cited}

Aitken, D.S., 1997, Digital version of the 1970 Topographic Map of the San Francisco Bay Region: U.S. Geological Survey Open-file Report 97-500, three sheets, map scale 1:125,000.

Ellen, S.D., Mark, R.K., Wieczorek, G.F., Wentworth, C.M., Ramsey, D.W., and May, T.E., 1997, Map Showing Principal debris-flow source areas in the San Francisco Bay Region, California: U.S. Geological Survey, Open-file Report 97-745 E, map scales 1:275,000 and $1: 125,000$.

Fitzgibbon, T.T., 1991, ALACARTE installation and system manual (version 1.0): U.S. Geological Survey, Open-File Report 91-587B.

Fitzgibbon, T.T., and Wentworth, C.M., 1991, ALACARTE user interface - AML code and demonstration maps (version 1.0): U.S. Geological Survey, Open-File Report 91- 587A.

Pike, R.J., 1997, Index to detailed maps of landslides in the San Francisco Bay Region,California: U.S. Geological Survey, Open-file Report 97-745 D.

U.S. Geological Survey, 1970, Topographic map of the San Francisco Bay region: 3 sheets, scale 1:125,000.

U.S. Geological Survey, 1972, Slope map of the San Francisco Bay region: 3 sheets, scale 1:125,000.

U.S. Geological Survey, 1993, Digital elevation models, data users guide 5 ( $3^{\text {rd }}$ printing, revised), Reston, VA, National Mapping Program, Technical Instructions, 48 p. [replaces 1987 ed. (38 p.) \& 1990 ed. (51 p.)]

Wentworth, C. M., and Fitzgibbon, T. T., 1991, ALACARTE user manual (version 1.0): U. S. Geological Survey Open-File Report 91-587C.

Wentworth, C. M., Graham, S.E., Pike, R.J., Beukelman, G.S., Ramsey, D.W., and Barron, A.D., 1997, Summary distribution of slides and earth flows in the San Francisco Bay Region, California: U.S. Geological Survey, Open-file Report 97-745 C, map scales 1:275,000 and $1: 125,000$. 